This item was submitted to Loughborough's Research Repository by the author.

Items in Figshare are protected by copyright, with all rights reserved, unless otherwise indicated.

\title{
Top executive compensation, regional institutions and Chinese OFDI
}

\section{PLEASE CITE THE PUBLISHED VERSION}

http://dx.doi.org/10.1016/j.jwb.2013.04.004

\section{PUBLISHER}

(c) Elsevier Inc.

\section{VERSION}

AM (Accepted Manuscript)

\section{PUBLISHER STATEMENT}

This work is made available according to the conditions of the Creative Commons Attribution-NonCommercialNoDerivatives 4.0 International (CC BY-NC-ND 4.0) licence. Full details of this licence are available at: https://creativecommons.org/licenses/by-nc-nd/4.0/

\section{LICENCE}

CC BY-NC-ND 4.0

\section{REPOSITORY RECORD}

Liu, Xiaohui, Jiangyong Lu, and Amon Chizema. 2013. "Top Executive Compensation, Regional Institutions and Chinese OFDI". Loughborough University. https://hdl.handle.net/2134/16713. 


\title{
Top Executive Compensation, Regional \\ Institutions and Chinese OFDI
}

\author{
Xiaohui Liu ${ }^{1}$ \\ School of Business and Economics \\ Loughborough University \\ Leicestershire LE11 3TU \\ U.K. \\ Email: X.Liu2@lboro.ac.uk \\ Telephone: +44 (0)1509 223349 \\ Fax: +44 (0)1509 223960 \\ Jiangyong Lu \\ Department of Strategic Management \\ Guanghua School of Management \\ Peking University, Beijing, China, 100871 \\ Email: lujiangyong@gsm.pku.edu.cn \\ Telephone: $+86(0) 1062767406$ \\ Amon Chizema \\ School of Business and Economics \\ Loughborough University \\ Leicestershire LE11 3TU \\ U.K. \\ Email: a.chizema@lboro.ac.uk \\ Telephone: +44 (0)1509 228807 \\ Fax: +44 (0)1509 223960
}

${ }^{1}$ Corresponding author 


\title{
Top Executive Compensation, Regional
}

\section{Institutions and Chinese outward FDI}

\begin{abstract}
Integrating agency and institutional theories, this paper examines the impact of top-executive compensation and regional institutions on the outward FDI (OFDI) of a sample of Chinese-listed firms. The results show that top-executive cash pay and equity ownership have a positive association with OFDI. Differing from previous studies focusing on cross-country institutional variances, we take variations in within-country institutions into account and find that regional institutions in terms of product markets, factor markets and legal systems play an important role in OFDI and positively moderate the governance role of managerial equity ownership.
\end{abstract}

Keywords: Top-executive pay; executive equity ownership; regional institutions; OFDI; China 


\section{Top Executive Compensation, Regional}

\section{Institutions and Chinese outward FDI}

\section{Introduction}

The impact of corporate governance on Outward FDI (OFDI) from emerging economies (EEs) has been recognised (Bhaumik, Driffield \& Pal, 2010; Liu, Li \& Xue, 2011; Strange et al., $2009)^{2}$. While most existing studies of corporate governance in EE firms have mainly focused on the role of ownership and board composition in OFDI, the impact of top-executive compensation on OFDI decisions has received little attention (Filatotchev \& Wright, 2011). In addition, prior studies on top-executive compensation have predominantly focused on an Anglo-American aspect and imposed a universal set of linkages between top-executive compensation and strategic choices without considering the distinct contexts in which firms are embedded, thus raising questions about the generalization of these findings in the context of EEs (Buck, Liu \& Skovoroda, 2008). There is, therefore, a lack of research on executive compensation and OFDI within firms from EEs, such as China, where the economy is in the process of transition from a centrally planned to a market-based economy (Child \& Tse, 2001). The role of corporate governance in general, and top executive compensation in particular, in such a context may differ from that of developed countries.

Despite increasing emphasis on the role of, and differences between, institutions of home and host countries in the context of OFDI (Peng, Wang \& Jiang, 2008), most existing studies regard within-country institutions as a homogeneous entity, with rare exceptions (Chan, Markino

\footnotetext{
${ }^{2}$ An emerging economy can be defined as a country that satisfies two criteria: a rapid pace of economic development, and government policies favoring economic liberalization and the adoption of a free-market system (Hoskisson, et al., 2000: p.249). A recent study (Hoskisson et al., 2013) classifies China as a mid-range emerging economy between developed economies and traditional emerging economies.
} 
\& Isobe, 2010; Meyer \& Nguyen, 2005). However, treating within-country institutions in such a way is inconsistent with the fact that large EEs are characterized by high levels of regional disparity, income inequalities and regional institutional diversity. These features may have a profound impact on EE firm internationalization.

Few studies have examined the role of top executive compensation in OFDI decisions and the inter-relationship between institutional factors and executive compensation in the context of EEs. To fill this research gap, this study adopts an integrated framework which combines agency theory and institutional theory to examine whether top-executive compensation affects OFDI by Chinese firms. This approach helps provide new insights into how regional institutional diversity affects corporate governance behaviour and OFDI strategies. The findings from the study will provide a better understanding of the complex relationship between executive compensation, institutional factors and OFDI decisions.

China represents an ideal laboratory for our research as the country is becoming a driving force of OFDI from EEs, and its OFDI increased dramatically from US\$0.9 billion in 1990 to US\$ 77.2 billion in 2012 (MOFCOM, 2013). In addition, China has adopted corporate governance concepts that were originally derived from developed economies. It is important to investigate how the adopted corporate governance practices interact with regional institutional environments and so affect firms' strategic decisions. More importantly, China, with 31 provinces, is well-known for its regional disparity and heterogeneous regional institutional environments (Meyer, 2008) ${ }^{3}$. The variation in regional institutional environments provides an

\footnotetext{
${ }^{3}$ According to the Economist (2011): "China is now the world's second-biggest economy, but some of its provinces by themselves would rank fairly high in the global league. ... Shanghai's GDP per person is as high as Saudi Arabia's (at purchasing-power parity).... At the other extreme, the poorest province, Guizhou, has an income per head close to that of India" (see more information in 'Comparing Chinese provinces with countries' at http://www.economist.com.hk/content/chinese_equivalents).
} 
appropriate context to examine the role of regional institutions in OFDI through their direct effect, and the complex inter-relationship between institutional factors and executive compensation.

The paper is structured as follows. The following section will focus on theoretical discussions and hypotheses development. Section 3 will describe our empirical model and data, and the results are presented in Section 4. Section 5 discusses the empirical findings; Section 6 concludes with policy and managerial implications.

\section{Theoretical framework and hypotheses}

The substantial rise of OFDI from EEs has received increasing attention (Deng, 2009; Luo, et al., 2010; Rui \& Yip, 2008). Existing research on EE OFDI suggests that OFDI strategic decisions are influenced by a variety of firm, industry, and country-related factors ( $\mathrm{Lu}$, et al., 2011; Yamakawa, Peng, \& Deeds, 2008). Extant research has been grounded in several theoretical perspectives, such as a learning perspective, resource-based view and institutional theory (Mathews, 2006; Yamakawa, et al., 2008). While some studies have found that firms from EEs consider OFDI as an effective way of obtaining advanced knowledge and catching up with Western MNEs (Deng, 2009; Mathews, 2006), others have shown that supportive government policies play an important role (Luo et al., 2010). A number of studies have adopted an integrated approach by examining how competitive advantages at firm level, industry competition and institutional environments jointly affect the motives for OFDI by Chinese firms (Lu, et al., 2011; Yamakawa, et al., 2008). The findings from existing studies have enhanced our understanding of the determinants of EE OFDI. 
Firms undertaking OFDI, however, are facing great uncertainties and challenges as international exposure increases the level of uncertainty, which may result in strategic errors such as misunderstanding consumer tastes or neglecting local regulations, or problems in accessing distribution channels (Mitchell, Shaver \& Yeung, 1992). In addition, increased internationalization may incur higher monitoring costs due to increased size and complexity (Hitt, Hoskission \& Kim, 1997; Roth \& O’Donnell, 1996). Several studies have examined the role of corporate governance in the internationalization of EE firms (Bhaumik et al., 2010; Filatotchev, et al., 2007). Bhaumik et al. (2010) have investigated the impact of the ownership structures on Indian firms' OFDI decision and have shown that family firms, and firms with concentrated ownerships, are less likely to invest overseas. Filatotchev et al. (2007) have explored the location choices of Taiwanese firms in mainland China and have found that the ownership structure of the parent company plays an important role in its FDI decisions.

Although existing studies have shown that executive compensation, as an important governance mechanism, influences firm strategies and outcomes, most prior studies have mainly examined the performance implications of executive compensation (Gomez-Mejia \& Wiseman, 1997; Rost \& Osterloh, 2009) and how internationalization affects executive compensation (Oxelheim, \& Randøy, 2005; Sanders \& Carpenter, 1998). Few studies have explicitly examined the impact of top-executive compensation on OFDI decisions by EE firms.

It is widely recognized that executive compensation is subject to institutional constraints, and its impact largely depends on the institutional environment within which firms operate (Aguilera \& Jackson, 2003). This is particularly the case in EEs such as China, Russia and India where regional disparities and institutional diversity are a common feature (Granville \& Leonard; 2010; Meyer, 2008). Regional institutional variations in large EEs may result in diverse OFDI 
decisions and affect the effectiveness of corporate governance. Hence, studying the impact of top executive compensation on OFDI should treat institutional characteristics as more than 'research background'. In order to remedy this omission, this study employs both agency and institutional theories as analytical lenses to examine the role of top-executive compensation in OFDI.

Agency theory has been widely applied to examine the relationship between firm performance, executive compensation and strategic choices (Brush, Bromiley \& Hendrick, 2000; Datta et al., 2009), and is based on the assumption that there may be divergence in the interests of agents (executives) and principals (shareholders), with the former likely to behave according to self-interest (Gomez-Mejia \& Wiseman, 1997). Hence, the theory argues that executive compensation can be used as an incentive for executives to align their interests with those of shareholders (Fama \& Jensen, 1983). The optimal CEO pay would minimize agency costs (Gomez-Mejia \& Wiseman, 1997). This approach theoretically underpins the two dimensions of incentive pay. On one hand, top-executive pay can be considered a motivational tool. As such it may incentivise managers to exhibit desirable behaviors and pursue feasible growth strategies, such as internationalization (Oxelheim, \& Randøy, 2005; Sanders \& Carpenter, 1998). On the other hand, executive compensation helps owners to reduce monitoring costs and narrow the divergence of interest between agents and principals (Buck, et al., 2008). In particular, the increased complexity associated with the degree and scope of internationalization makes it difficult for the board to monitor senior executives (Filatotchev \& Wright, 2011). Hence, topexecutive compensation, especially equity-based incentives, is used as a pay reward which links top-executive pay to share price performance. This type of equity reward may lead to an increase in internationalization. 
However, agency theory is 'under-socialized' (Aguilera \& Jackson, 2003) and, on its own, may not be adequate to explain how executive compensation affects the strategic decisions of firms in the context of EEs. Prior studies on agency theory have concentrated on a static theorizing of the principal-agent perspective without considering the context in which agency theory issues are derived (Filatotchev \& Wright, 2011).

As discussed above, there exist considerable institutional variations across regions within China due to its gradual approach to economic and institutional reform (Child \& Tse, 2001; Meyer, 2008). Regional/local governments are granted the authority and responsibility for regional economic development and they control about half of the total governmental budget due to decentralisation (Naughton, 1995). Local governments are able to implement policies which affect the development of product markets, factor markets, and market-intermediate institutions and legal systems. ${ }^{4}$ As a result, firms' behaviour and strategic choices are largely affected by regional institutional environments (Schlevogt, 2001; Chan, Markino \& Isobe, 2010; Gao et al., 2010). According to the World Bank Group (2008), in Zhejiang Province, it takes 30 days to start a business, whereas in Qinghai Province, it takes 47 days to do so. Moreover, it is relatively easy for businesses to get credit in well-established regions. Businesses need 8 days to get credit from banks in Shanghai, but it takes 20 days to do so in Qinghai Province. These institutional differences affect the speed of responding to business opportunities in the international market by firms in different regions, thus resulting in differences in OFDI activities. Hence, institutional theory serves as an additional theoretical lens that allows consideration of the impact of regional

\footnotetext{
${ }^{4}$ Factor markets refer to markets where the services of the factors of production, such as labor and capital, are exchanged in the labor market, the capital market, the market for raw materials and the market for management.
} 
institutional environments on firm strategic choices directly and indirectly through their interaction with corporate governance factors.

\section{Top-Executive Compensation}

Among the factors affecting OFDI, top executives play an important role in the strategic decision-making process. Agency theorists (Jensen \& Murphy, 1990) propose that top-executives are more likely to be significantly influenced by their remuneration and argue that the design of an agent's compensation represents an important mechanism for mitigating agency problems and associated costs. The aim of such design is to ensure proper alignment of the interests of managers with those of owners. Thus, top-executive compensation acts as a mechanism through which a convergence in interests between the agent and principal can be achieved.

OFDI decisions are interrelated organizational outcomes of the firm's strategic dynamics and may depend upon the risk preferences of both managers and key stakeholders (Aulakh, Masaaki \& Teegen, 2000). Despite the organizational complexity and risk associated with internationalization, by seeking resources and new markets through OFDI, firms are likely to create shareholder value. From an agency theory perspective, executive remuneration plays an important role in encouraging the creation of shareholder value, achieved in this case by the strategic choice of OFDI. Previous findings have suggested that top-executive pay has a direct impact on international diversification (Tihanyi et al., 2009). Moreover, some scholars have argued that executive compensation is positively related to the organizational complexity that executives manage and specifically to the level of internationalization (Sanders and Carpenter, 1998). In addition, managers' perceptions may change given the type of incentive. Hence, 
executive compensation is crucial to the strategic decision-making of EE firms and may affect OFDI decisions (Filatotchev \& Wright, 2011). There are two main reasons.

First, top executives are more likely to be motivated to take on the challenges in pursuing growth via OFDI and exhibit behavior that is in the interest of shareholders when their rewards are at desirable levels (Mustee, Datta \& Herrmann, 2008). In other words, top executives receiving a higher level of pay may be encouraged to devote more attention to OFDI in order to seek to maximize shareholder value. A high level of executive pay not only motivates them to handle the complexity of overseas operations, but also enables the firm to attract and retain experts who are capable of dealing with internationalization. Therefore, executive pay as a motivational tool may significantly affect senior managers' willingness to engage in international expansion.

Second, direct equity ownership helps to align management interests with those of shareholders (Murphy, 1999). Incentives that induce top executives to take a long-term view are likely to result in different choices than those with a short-term focus (DeFusco, Zorn \& Johnson, 1991). Executive equity ownership helps to overcome the problem of the 'shortsightedness' of top executives as they will still be eligible for future gains in their companies' share price even if their tenure terminates (Wong, 2011). In other words, an increase in equity ownership makes executives' wealth more dependent on their companies' long-term performance. Hence, the alignment effect of managerial equity ownership may help to reduce the agency problem and provide an incentive for top executives to support internationalization, which may raise the competitiveness and performance of their companies in the long run (Jenkins \& Seiler, 1990). Managerial equity ownership can also empower managers to initiate internationalization as a growth strategy (Zahra et al., 2000) and may encourage managerial risk- 
taking in internationalization (Rajgopal \& Shevlin, 2002; Sanders \& Hambrick, 2007). It may be in the top executive's interest to undertake OFDI, as the increased size and scope of their firms through OFDI will increase their pay and prestige (Jensen \& Murphy, 1990). In summary, we argue that managers with a high level of cash pay and equity ownership may be motivated to pursue internationalization strategy as a growth option and may respond more positively than they otherwise might to opportunities in the international market (Palmer \& Wiseman, 1999). Therefore, we propose:

Hypothesis 1a: Top-executive pay positively affects the extent of OFDI of Chinese firms. Hypothesis 1b: Top-executive equity ownership positively affects the extent of OFDI of Chinese firms.

\section{Regional Institutional Environments}

North (1990) defined institutions as the humanely devised constraints that structure organizational interaction through human agency; the institutional environment is composed of a set of social, legal and political tenets that govern economic activity. Thus, in a given environment, institutions define and limit the set of choices of individuals or organisations. In this sense, institutions are perfectly analogous 'to the rules of the game', (North, 1990, p. 3-4). Among the variety of formal institutions, governance as well as legal and regulatory institutions drive, to a large extent, business activities and provide support to social and economic institutions such as product and factor markets (Globerman \& Shapiro, 2003).

Previous studies on Chinese OFDI based on the institutional perspective have examined the role of government policy in promoting OFDI (Luo, et al., 2010; Lu, et al., 2011). However, these studies have narrowly focused on the impact of regulatory factors and state support. The 
impact of different dimensions of the institutional environment, such as marketization and market supportive institutions across regions within China, is underexplored. Our research complements previous studies (Cui and Jiang, 2012; Lu, et al., 2011) by examining how different dimensions of regional institutional environments affect Chinese OFDI.

Following decentralization, a step towards greater marketization, local governments in Chinese provinces have since assumed wide discretionary powers in managing the business environment in which local firms operate. Market-oriented reforms have resulted in decisive progress, but large gaps still exist among different regions (Fan et al., 2003). According to Fan et al. (2003), the variation in the institutional environments can be better understood by examining the process of marketization that is based on three major aspects: 'degree of product-market development,' 'degree of factor-market development' and 'development of marketintermediaries and legal environment system'. Based on this classification, we examine three main aspects of regional institutional environments, including a product market, a factor market as well as market-intermediate institutions and legal systems. We argue that a fine-grained analysis of the effects of different aspects of institutional components on OFDI is important and enables us to capture the complexity of the different dimensions of regional institutional environments and firm internationalization, and their moderating effect on top executive compensation.

In the context of a large EE, a region with a well-established institutional environment may have developed an effective product market, factor market as well as market-intermediate institutions and legal systems. Firms operating in a well-established regional institutional environment will have already been exposed to some market-based rules and will be able to develop capabilities which can be exploited by international expansion. First, a well-established 
product market, including market-determined price setting and a low level of regional protection, is credited with legitimacy (Carroll and Hannan, 1995); this encourages new entrants, which increases competition (Arora and Gambardella 1997). The competitive pressure pushes firms to cut prices and improve product performance. The offsetting force of competition places a ceiling or threshold on the equilibrium number of firms (Carroll \& Hannan, 1995), leading to the mortality, the exit or the seeking of new opportunities abroad. In particular, intensified competition in domestic regional markets may result in vigorous efforts to penetrate foreign markets in order to sustain growth, or even to fill capacity ( $\mathrm{Lu}$, et al., 2011). A well-functioning product market also helps firms to undertake OFDI by building foundations for international expansion, such as being familiar with market-based rules and increasing efficiency. In particular, the development of market mechanisms increases the efficiency of resource allocation in the industry, which helps firms to achieve economies of scale domestically, thus serving as a stepping-stone for international expansion (Gao et al., 2010).

In addition, a well-developed factor market also helps firms to raise funds through the financial sector to undertake OFDI. However, in Chinese regions with underdeveloped institutional environments, the factor market is usually dominated by non-market forces and is often subject to local protection due to a lack of effective contract enforcement (Fan et al., 2010). Such an underdeveloped factor market may distort market competition and result in monopoly. Firms operating in such an environment may have few incentives to internationalize as they either enjoy preferential treatment in their regional markets or lack the capability to compete in foreign countries with market-based rules.

Finally, market-intermediate institutions and legal systems determine the extent of protection for businesses, intellectual rights and consumers' rights, and facilitate business transactions. This 
suggests that institutional environments with better legal systems are more likely to support business initiatives. In the context of China, the economic reform starting in the late 1970s achieved great progress in its legal systems but with uneven regional improvements, especially in law enforcement. Fan et al. (2003) argue that outstanding lawyers and reputable law firms are mainly located in the politically and economically developed centers and coastal cities; whereas in the western and inland regions well-served law consultation and qualified auditing service are difficult to obtain. Relatedly, Wang et al. (2007) found that in the eastern coastal regions of China, or regions with better institutional environments, the degree of marketization is higher than that in the central and western regions, or regions with a poorer institutional environment.

In the case of China as well as in general, therefore, a well-developed institutional environment is able to motivate local firms to improve efficiency and competitiveness. Wellestablished regional institutional environments may also facilitate OFDI by providing an efficient common infrastructure, and by initiating supportive policies (McEvily \& Zaheer, 1999). Firms from more developed institutional environments are more likely to have greater access to the resources and information required to engage in OFDI (Luo et al., 2010). The development of intermediate institutions also reduces the transaction and agency costs, and the uncertainties for firms in undertaking OFDI. Hence, we propose:

Hypothesis 2: Well-developed regional institutional environments positively affect the extent of OFDI of Chinese firms.

Interrelationships between Top Executive Compensation and Regional Institutional Environments 
In the previous section we considered the direct effect of top-executive compensation and institutional factors on the OFDI of EE firms. However, these factors are not orthogonal and they may interact with each other. In other words, the relationship between executive compensation and OFDI may be moderated by institutional contexts in which firms are embedded. The effectiveness of executive incentives may be contingent on regional institutional factors, namely the development of product markets, factor markets and market-intermediate institutions and legal systems (Firth, Fung \& Rui, 2007). These institutional factors may enhance the governance roles of executive compensation through affecting managerial behavior (Young et al., 2008).

The institutional environment may affect managerial behaviour in a number of ways. First, product markets can act as a control mechanism on managerial behaviour (Hart, 1983). Firms in regions with well-developed product markets are able to rely on the market to set up prices and they face a low level of regional trade barriers. Such features of the product markets foster competition, and firms facing great competition at home are more likely to seek international expansion. Hence, increased competition may put pressure on top executives to undertake OFDI. In this way, well-established regional product markets help reinforce the positive effect of topexecutive pay.

Second, well-established factor markets act as an important monitoring mechanism which helps enhance the governance role of top-executive compensation. Owing to the power derived from the lending and advice they provide to firms, financial institutions may influence the effectiveness of corporate governance. Studies in other governance contexts have shown the role of banks in the determination and disclosure of executive compensation (Chizema, 2008). However, in China the distribution of financial institutions is uneven across regions. For example, the headquarters of the largest state banks and all big commercial banks, including 
foreign banks, are mainly located in the eastern region. Indeed, the concentration of banks in the eastern provinces enhances liquidity provision to firms in these provinces (Brandt \& Zhu, 2000) accompanied by more bank monitoring on various governance issues including executive compensation.

A flexible and functional labor market puts considerable pressure on top executives who may be forced to make strategic decisions on behalf of stakeholders. It also helps minimize executives' opportunistic behavior, given that hiring and firing managers becomes relatively easy (Shinkle \& Kriauciunas, 2010). Hence, a fluid regional labor market is able to restrain managers' opportunism and induce them to make value-enhancing strategic choices, such as OFDI. By the same logic, a well-established capital market which acts as a monitoring mechanism helps scrutinize managers (Shinkle \& Kriauciunas, 2010). In addition, effective market-intermediate institutions and legal systems are able to protect investors and reduce the possibility of managerial opportunism, thus lowering agency costs (La Porta, Lopez-De-Silanes \& Shleifer, 1998). In summary, well developed regional product and factor markets, as well as effective market- intermediate institutions and legal systems, play an important role in monitoring top executives and reduce the possibility that top executives may behave opportunistically by pursuing their self-interest instead of the long-run growth of the company, and may help facilitate OFDI through reinforcing the positive impact of top executive compensation on OFDI decisions. Hence, we hypothesize

Hypothesis 3a: Well-developed regional institutional environments positively moderate the impact of top-executive pay on the extent of OFDI of Chinese firms.

Hypothesis 3b: Well-developed regional institutional environments positively moderate the impact of top-executive equity ownership on the extent of OFDI of Chinese firms. 


\section{Data and methodology}

\section{Sample}

We test our hypotheses based on a sample of Chinese firms that were publicly listed on the Shanghai and Shenzhen stock exchanges. We chose 2002 as the starting year for two reasons: first, OFDI by Chinese firms surged after China's access to WTO at the end of 2001, and second, annual reports for years earlier than 2002 provide less detailed information on subsidiaries. Constrained by the availability of regional institutional indices, the sample period ended in 2007. We focused on firms whose annual reports can be obtained from the Shanghai and Shenzhen stock exchanges, the website of the China Security Regulation Committee (CSRC), and the websites of listed firms for the years 2002 through 2007. We collected information on overseas subsidiaries from listed firms' annual reports for 2002-2007. We excluded firms in the financial sector as financial firms tend to have different financial structures and ways of measuring their performance and internationalization (Lien, Piesse, Strange, \& Filatotchev, 2005). In addition, the financial sector is heavily regulated by the Chinese government. Hence, it would be difficult to examine the role of the regional institutional environment in such a tightly regulated sectoral context. Our sample consisted of 1,071 listed firms in the manufacturing sector. All of the variables used in the study were collected from the annual reports of the sample firms except for the measurements of regional institutional indices.

\section{Dependent variables:}

We calculated two dependent variables to measure OFDI. The first dependent variable, the Extent of OFDI across different countries, is defined as $\sum_{c}\left[S_{c} * \ln \left(1 / S_{c}\right)\right]$, where $S_{c}$ is the share of 
investment in country $c$ to total foreign investment and $\ln \left(1 / S_{c}\right)$ is the logarithm of the inverse of the investment share. The measure considers both the number of countries in which the firm operates and the relative importance of each country to the firm (Hitt et al., 1997). The second dependent variable is measured by the Share of OFDI in firms' total investment.

\section{Independent variables:}

There were two main forms of top-executive compensation in Chinese-listed firms during the sample period. One consisted of salary and bonuses. The other was equity ownership. Stock options were virtually absent within Chinese-listed firms. Therefore, we used two measures to proxy top-executive compensation. The first measure was top-executive (TE) pay, including salaries and bonuses. This was calculated as average pay for the three highest-paid top executives at 2000 prices as the disclosure of top-executive pay was only reported as aggregate salary and bonuses for the three highest-paid executives in the annual reports of Chinese-listed firms ${ }^{3}$. We used the log value of TE pay in our estimations. The second measure, top-executive (TE) equity ownership, is expressed as the average percentage of total equity in a firm that is owned by the three highest-paid top executives based on prior studies (Goranova, et al., 2007; Himmelberg et al., 1999; Lu, et al., 2010).

Although institutions could either be formal (e.g. legal and economic) or informal (such as culture), we focused on the former for two reasons. First, China as an economy in transition is witnessing rapid formal institutional changes from central planning to a market economy. Second, unlike informal institutions, formal ones have a more direct effect on top-executive pay and business decisions such as OFDI (Buck et al., 2008). The institutional indices used in the study were constructed by The National Economic Research Institute (NERI) of China and the

\footnotetext{
${ }^{3}$ Year 2000 prices were used to convert the nominal executive pay into a real variable by deducting the impact of inflation on top executive pay. Our sample starts in 2002, and China jointed the WTO in 2001. Therefore, using year 2000 prices as a base year prices enables us to take the impact of China's WTO entry on prices which may be reflected in executive pay.
} 
China Reform Foundation (Fan, Wang \& Zhu, 2010). ${ }^{5}$ The NERI indices are the official and most comprehensive measures of China's multifaceted institutional development and have been widely used in recent studies (e.g., Du, Lu, \& Tao, 2008; Gao et al., 2010; Wang, Wong, \& Xia, 2008). Raw data used in the construction of the NERI indices were mainly from the statistical yearbooks of the National Statistics Bureau of China, which contain statistical information on prices, the administration of industry and commerce, the courts, consumers' associations, and also government statistical information collected from bank surveys, surveys of entrepreneurs, and surveys of rural households. The indices covered the period 2002-2007 and have not been updated beyond 2007, thus defining our sample period. The NERI indices comprehensively capture the provincial differences in institutional environments over time and are categorized into five dimensions: (1) the relationship between government and markets; (2) the development of the non-state enterprise sector; (3) the development of product markets; (4) the development of factor markets and (5) the development of market-intermediate institutions and legal systems. Detailed information on how each dimension was assessed is presented in Appendix Table 1.

As we focus on how the impact of the development of economic institutions and legal systems on top executive compensation and OFDI, we mainly use three indices, namely the index of product markets, the index of factor markets and the index of market-intermediate institutions and legal environment. Specifically, the index of product markets is assessed by the extent of market-determined product prices and the reduction of local protectionism or local trade barriers. The factor market index is measured by the development of the financial sector, the extent of labor mobility in labor markets and the ratio of technology transactions to technical

\footnotetext{
${ }^{5}$ For detailed calculation of the NERI index, please refer to Fan, G., Wang, X. \& Zhu, H. (2010). NERI Index of Marketization for China's Provinces: 2009 Report (in Chinese), Economic Science Press, Beijing.
} 
personnel. The index of market-intermediate institutions and legal systems is measured by the development of market intermediate mechanisms and the extent to which legal systems protect businesses, intellectual property rights and consumers' rights. Taking year 2007 as an example, Shanghai had the highest indices in terms of factor markets (11.93) and market-intermediate institutions and legal systems (16.61), and Zhejiang Province had the highest index of product markets, whereas Qinghai Province had the lowest indices of product markets (5.52) and marketintermediate institutions and legal systems (2.79), and Xinjiang had the lowest index of factor markets (2.42). These indices show substantial differences in institutional environments across provinces in China (see Appendix Table 2 for more details).

\section{Control variables:}

State ownership may affect firms' internationalization strategies. Thus, we controlled for state shareholding, which is calculated as the percentage of shares owned by the central government, local governments and government related agencies, to capture the effect of direct state intervention. We followed the methodology of Delios, $\mathrm{Wu}$ and Zhou (2006) to categorize ownership in Chinese-listed firms according to the ultimate identity of shareholders, and updated the ownership category data for the sample period. We used a dummy variable to capture the impact of the government's industrial policy towards OFDI, taking the value 1 if the industries are prioritized by the government, which encourages Chinese firms to invest in these industries abroad (zero otherwise) based on the guidance for overseas investment issued by the Chinese government (MOFCOM, 2004). We also control for foreign shareholding which was measured as the percentage of equity shares owned by foreign investors. 
We controlled for the impact of board directors and independent directors by including the variables of board size and independent directors in our estimations (Lu et al., 2010). The former was measured as the total number of board directors, while the latter was calculated as the ratio of the number of independent directors to the total number of board directors. We also controlled for top executives' international experience in OECD countries. This is measured as a dummy variable which is value 1 if top executives studied and/or worked in OECD countries, and zero otherwise. We collected such information from the "Profile of Directors and Senior Managers" section of the company's annual reports. By including this control variable, we aimed to reflect the fact that China has recently attracted a large number of return migrants who worked and/or were educated in OECD countries and have now returned to China (Liu et al., 2010). These returnees may play an important role in the internationalization of Chinese firms. We controlled for firm size since larger firms typically have more slack resources for internationalization, which is measured by the logarithm of firm total assets. Firm age is controlled for as a proxy of experience and resources. We controlled for a firm's previous performance as measured by the return on assets in the previous year (Mani, Antia, \& Rindfleisch, 2007). We also included the logarithm of intangible assets to control for the impact of firms' technological capability on internationalization. According to the Chinese accounting standards, intangible assets are defined as long-term non-monetary assets without physical forms held by enterprises, including patents, non-patent technology, trademarks, copyrights, land use rights and concessions. We used industry dummies to control for industry effects in the manufacturing sector and the primary sector. We also controlled for time effects by using year dummies.

\section{Methodology}


The relationship between top-executive compensation and OFDI is not clear-cut, and reverse causation from OFDI to executive pay may exist (Sanders \& Carpenter, 1998). Endogeneity arises when the factors that are supposed to affect a particular outcome, depend themselves on that outcome. In order to identify whether there is a reciprocal relationship (i.e. endogeneity) from OFDI to executive pay, we first conducted panel Granger causality tests ${ }^{6}$. If reverse causation exists, the impact of executive compensation on internationalization would be overstated when using the OLS. Instead, the generalized method of moments (GMM) should be applied in order to take reverse causation into account. The GMM is widely used to deal with the endogeneity problem as it is sufficiently flexible to control for unobserved heterogeneity and reverse causality. In particular, Blundell and Bond (1998) suggest that GMM estimation is an appropriate approach to short panel data since it allows for a large set of instruments of first differences and, therefore, exploits fully all of the available moment conditions. This yields better predictions for the endogenous explanatory variables in the finite sample.

\section{Empirical results}

Table 1 presents descriptive statistics and the correlation matrix for the variables used in this study. According to our data, the highest-paid three top executives, on average, earn 2.7 million RMB which is equivalent to US\$344,000, and hold $3 \%$ of the total shares of their companies. The average number of board members is nine and that of independent directors is three. The state share holdings account for $44 \%$ of the ownership of the sample firms, whereas the average

5 Granger causality tests are widely used to identify the causal relationship between variables (Granger, Huangb \& Yang, 2000; Nair-Reichert \& Weinhold, 2001). Variable X is said to cause variable Y in the Granger sense if variable Y can be better explained when the lagged variable $\mathrm{X}$ is taken into account. 
foreign share holdings are about 5\%. We have compared whether there are differences in the main characteristics of the sample firms based on state share holdings, using $10 \%$ and $60 \%$ of state share holdings as cutting points. The results show that firms with over $60 \%$ of state holdings have undertaken more OFDI. There was no significant difference in top-executive pay in terms of their salary between firms with majority state holdings and those without. However, top executives in firms with majority state holdings own fewer shares than those in privately owned firms.

To provide detailed information on how top-executive pay was designed, we interviewed eight top executives from the sample firms, including five CEOs, two Vice Presidents and one Chief Finance Officer (CFO). According to our interviews, the value of total shares owned by top executives is greater than their salary. Seven interviewees confirmed that the value of the total shares they hold is more than five times of their salary. The value of shares rewarded annually accounts for $30 \%-40 \%$ of their salary. They all expressed the view that equity ownership has become an increasingly important mechanism of performance-related pay for top executives. All our interviewees indicated that they were given their companies' shares directly and were also offered shares at less than $20 \%$ of the market prices, as pay rewards. The interview evidence indicates that fixed salary accounted for between $50 \%-70 \%$ of the total pay. The rest of pay is linked to performance. While most case companies used profits and sales growth as performance measures, one company also linked performance indicators to the specific positions of top executives. For example, the Chief Technology Officer's performance was measured against R\&D project completion and new product development, whereas the marketing director's performance was measured against sales growth and an increase in market share. 
Apart from independent board members, the board of directors includes top executives and shareholder representatives based on their share ownership. Top executives, as non-independent directors, account for more than $50 \%$ of board members, whereas one third of board members are independent directors. On average, there are five top executives in the sample firms. It is unlikely that independent directors become the majority. Our interviewees stated that the State does not have direct involvement in selecting the board of directors even in State shareholding companies.

The sample firms invested in 63 countries, as shown in Table 2, and their overseas investment accounts for nearly $11 \%$ of total investment. According to interview evidence, the sample firms have undertaken merger and acquisitions or established wholly-owned subsidiaries in developed countries, but have formed joint ventures as the entry mode in other emerging economies, such as in Africa and Asia. Most of the variables have the expected signs. There is a positive correlation between the two top-executive compensation variables and the two measures of OFDI.

Insert Tables 1 and 2 near here

The results from the causality tests summarised in Table 3 reveal the existence of reverse causation from internationalization to executive pay, suggesting that the two executive compensation variables are not exogenous. Based on the results from the causality tests, we adopted the GMM as our estimation method and used lagged first differences of dependent and independent variables as instrumental variables which are commonly used to address the endogeneity problem in GMM estimation (Baum, Schaffer, \& Stillman, 2003). The consistency of the GMM estimator depends on the validity of the instrumental variables used in the 
regression. We addressed this issue by conducting the Sargan test which is used to test whether the instrumental variables are uncorrelated to residuals and whether they are acceptable instruments. The insignificant results from the Sargan test in Tables 4 and 5 indicate that the instrumental variables are appropriate.

Insert Table 3 near here

We use two proxies, Extent of OFDI and Share of OFDI as the dependent variables. Table 4 and Table 5 present the results using GMM estimators. Extent of OFDI is the dependent variable in Model 1 - Model 7, whereas Model 8 - Model 14 are estimated using Share of OFDI as the dependent variable. Model 1 and Model 8 include controls only and this helps to verify whether the main independent variables contributed to the explanatory power of the models used. The results show that the adjusted $\mathrm{R}^{2}$ value is improved when the explanatory variables and interaction terms are included in the models in Tables $4 \& 5$. For example, when the index of market-intermediate institutions and legal systems was added, the adjusted $\mathrm{R}^{2}$ value increased to 0.153 , showing that the variable of market-intermediate institutions and legal systems has greater explanatory power for the dependent variable, OFDI. The results of Models 1 and 8 show that the variable of foreign shareholding is positive and statistically significant, indicating that foreign ownership has a positive impact on Extent of OFDI and Share of OFDI. The variable of state shareholdings is positive, but insignificant, whereas firms in the industries which are prioritized by the government for overseas investment tend to undertake OFDI. The variable of board size is negative and statistically significant in Model 8, suggesting that the larger the board, the less the firm undertook overseas investment. This may indicate that larger boards have difficulty reaching consensus on important decisions, such as OFDI strategic decisions, or may have a slow response to opportunities in foreign countries (Golden and Zajac, 2001; Van Den 
Berghe and Levrau, 2004). The variable of independent directors has a positive sign, but is statistically insignificant.

The variable of returnee executives is positive and significant, and the result suggests that executives with international experience are more likely to be the promoters of internationalization. The coefficient of the variable of intangible assets is negative and significant, indicating that Chinese-listed firms tend to undertake OFDI to seek strategic assets rather than exploiting their intangible assets. Firm size and firm age positively affect internationalization, suggesting that large firms and well-established firms are actively engaged in internationalization. However, the variable of lagged returns on assets is insignificant, showing firm performance is not a fundamental force in firm internationalization.

\section{Insert Tables 4 and 5 near here}

The results of Models 2-4 in Table 4 and Models 9-11 in Table 5, which add the explanatory variables, show that the executive pay and equity ownership variables are statistically significant, suggesting that executive compensation positively affects OFDI, thus supporting Hypothesis 1a and Hypothesis 1b. We further interpret the main coefficients as follows. It can be seen that one standard deviation of increase in top-executive pay leads to an increase in Extent of OFDI, ranging from 0.2 percent to 0.7 percent when the three institutional indices were used in the estimations, whereas one standard deviation of increase in top-executive equity ownership results in an increase in Extent of $O F D I$, ranging from 2.5 percent to 8.4 percent (Models 2-4 in Table 4). Moreover, one standard deviation of increase in top-executive pay is associated with 1.9 percent to 2.6 percent increase in Share of $O F D I$, respectively, whereas one standard deviation of 
increase in executive equity ownership leads to an increase in Share of OFDI, ranging from 37.5 percent to 38.6 percent (Models 9-11 in Table 5).

The three institutional indices are positive and significant, thus confirming that wellestablished institutional environments in terms of product markets, factor markets and marketintermediate institutions and legal systems help firms to undertake OFDI as hypothesised in H2. Specifically, one standard deviation of increase in the indices of product markets, factor markets and market-intermediate institutions and legal systems leads to an increase in Extent of OFDI, ranging from 0.3 percent to 1.1 percent (Models 2-4 in Table 4). Similarly, one standard deviation of increase in the indices leads to an increase in Share of OFDI, ranging from 0.8 percent to 1.5 percent (Models 9-11 in Table 5).

In Models 5-7, and Models 12-14, the interaction effects between the variables of executive compensation and the institutional indices were taken into account. The interaction terms between the three institutional indices and the variable of executive equity ownership are positive and significant, indicating that institutional development in terms of product markets, factor markets and market-intermediate institutions and legal systems positively moderates the governance role of executive equity ownership. However, the interaction terms between topexecutive pay and the indices of factor markets and market-intermediate institutions and legal systems are insignificant. Hence, Hypothesis 3a receives partial support. The results show that regional institutional environments, including product markets, factor markets and marketintermediate institutions and legal systems, positively moderate the impact of equity-based incentives on OFDI by Chinese-listed firms, thus supporting Hypothesis $3 b$. It is shown that one standard deviation of increase in the three institutional indices enhances the impact of top- 
executive equity ownership on Extent of OFDI, ranging from 0.6 percent to 1 percent (Models 57 in Table 4). In Models 12-14 in Table 5, one standard deviation of increase in the indices of product markets, factor markets and market-intermediate institutions and legal systems strengthens the impact of top-executive equity ownership on Share of OFDI, ranging from 4.2 percent to 6.1 percent. However, only the index of product markets has a significant moderating effect on top-executive pay; one standard deviation of increase in the index of product markets enhances the impact of top-executive pay on Share of OFDI by 0.1 percent.

\section{Discussion}

This study examines the impact of executive compensation and regional institutions on OFDI for a sample of Chinese-listed firms from 2002-2007. Integrating agency theory with institutional analysis, we extend the existing literature by investigating how top-executive compensation and regional institutions jointly influence OFDI decisions. We find that top-executive compensation in terms of cash pay and equity ownership is positively associated with OFDI. The finding shows that executive compensation plays a key role in OFDI. Executive compensation is an important mechanism through which managers are motivated to adopt an OFDI strategy. Executive equity ownership is only a recent phenomenon in China but it is an increasing trend even though it is still relatively low by international standards. Our results on executive equity ownership may reflect the fact that market-oriented executive compensation has encouraged managers' willingness to make viable and longer-term decisions such as internationalization.

Our findings show that heterogeneous regional institutional environments significantly affect OFDI. Firms in provinces with well-established institutional environments are more likely to undertake OFDI due to competitive product markets, efficient factor markets and sufficient support from market-intermediate institutions and legal systems. We further investigate the 
complex interrelationship between top-executive compensation and regional institutional environments. We explicitly examine the interplay between executive compensation and these institutional factors, and investigate how the latter affect firm strategic choices indirectly through their interaction with the former. Our findings show that well-established product markets, factor markets and market-intermediate institutions and legal systems play an effective monitoring role and help reduce managerial opportunistic behavior, thus enhancing the corporate roles of equitybased incentives. OFDI decisions are jointly affected by equity-based incentives and regional institutional development, and well-developed regional environments encourage top executives to undertake OFDI.

Our study makes a number of important contributions to the existing literature. First, adopting an integrated framework which combines both agency and institutional theories, we conduct a systematic and detailed analysis of executive compensation, regional institutions and OFDI by Chinese-listed firms. This approach enables us to investigate the interrelationship between executive compensation and institutional environments in which agency issues are derived. While institutional factors have remained as 'background' in most studies on corporate governance, especially the role of executive compensation, our study has brought institutional factors from background to forefront, thus providing new insights into how the institutional environment affects corporate governance behaviour and OFDI strategies.

Second, challenging prior studies which treat within-country institutions as a homogeneous variable, we explicitly examine how variations in regional institutional environments affect OFDI directly and indirectly through interaction with executive compensation. Thus, the study is able to take the special characteristics of a large EE into account. More importantly, disaggregating broad institutional environments into three institutional factors, we have found 
that well-established product markets, factor markets and market-intermediate institutions and legal systems play an effective monitoring role and help reduce managerial opportunistic behavior, thus enhancing the corporate roles of equity-based incentives. Hence, the findings from the study help identify which institutional factors are more salient in shaping the complex relationship between top-executive compensation and regional institutional environments. Our detailed analysis of different aspects of regional institutional environments also extends prior studies which have mainly focused on the role of government policy and state support in OFDI by Chinese firms.

Third, unlike previous research which assumes straightforward causation between independent and dependent variables, we employ an empirical method and panel data to take reverse causation into account. In particular, the results from our causality test show that there are reciprocal causation effects between executive pay and OFDI and assuming one-way causation may lead to the overestimation of the effect of executive pay or internationalization.

\section{Managerial Relevance}

Our study examines the impact of executive compensation and regional institutional environments on OFDI, and offers a number of policy and managerial implications. First, our findings show that there is a positive association between top-executive compensation and OFDI decisions by controlling the reverse causation. This suggests that executive compensation, including top-executive equity ownership, helps to mitigate principal-agent conflicts in Chineselisted firms. Undertaking OFDI is considered an effective means of achieving better performance or overcoming domestic constraints, such as fierce domestic competition. International expansion may help to increase sales growth and share prices and in turn, top executives may 
benefit through an increase in performance-related pay. Top executives are more likely to be motivated to undertake OFDI when their performance-related pay is directly linked to international sales growth. Hence, executive compensation should be designed to fit firms' international expansion strategies and motivate senior managers to pursue such strategies. Second, our results show that well-established regional institutional environments in terms of product markets, factor markets, and market-intermediate institutions and legal systems encourage firms to undertake OFDI. Hence, policy makers not only promote OFDI through direct state support, but also take measures to foster the development of product and factor markets, and market-intermediate institutions and legal systems. Well-established institutional environments may act as a substitute for direct state support. Finally, our findings indicate that the impact of executive equity ownership is contingent on regional institutional environments. This suggests that developing regional institutional environment not only helps to promote OFDI directly, but also indirectly affects the effectiveness of executive equity ownership. Hence, developing these institutional factors is a crucial task facing the governments of EEs.

Limitations and future studies

Notwithstanding the relevance and novelty of this study, we identify some limitations and suggest avenues for further research. First, our sample contains only Chinese-listed firms, while unlisted firms, usually smaller ones, were not included in the study. Consequently, a full investigation of the role of executive compensation on internationalization in wider organisational contexts is still awaited. Second, only aggregate salary and bonuses for the three HPEs are disclosed in Chinese-listed companies. Using average top-three director pay in our estimation may lack variation relative to individual pay and may have limited power to reveal the complex relationship between executive pay and internationalisation. Future studies should 
further verify the impact of executive compensation on OFDI when more fine-grained data on individual top-executive compensation are available. Third, our study only focuses on whether firms undertook OFDI during the sample period, but we were unable to examine how executive compensation affects entry mode selection due to data availability. Future research should investigate the role of executive compensation in entry mode choices. Finally, our study has taken endogeneity into account using the GMM, which presents an extension of prior studies in this area, and the results show that OFDI of Chinese-listed firms is jointly determined by multilevel factors including regional institutional environments and a firm's executive compensation. Future studies could extend the analysis by adopting a multilevel analysis technique. This multilevel analysis may help to provide a more complete picture of the OFDI by EE firms.

\section{Conclusion}

Using panel data analysis, we examine the impact of top-executive compensation and subnational institutions on OFDI for a sample of Chinese-listed firms. We found a positive association between top-executive compensation and OFDI in Chinese-listed companies by controlling reverse causation from internationalization to executive compensation. Our findings indicate that regional institutional environments are positively associated with OFDI. We have further investigated the interaction effect between regional institutional environments and topexecutive compensation. The results suggest that regional institutional environments positively moderate the governance role of executive equity ownership. Our findings call for more studies from different countries to further unpack the complex relationship between executive compensation and OFDI. 


\section{References}

Aguilera, R., \& Jackson, G. (2003). The cross-national diversity of corporate diversity: dimensions and determinants, Academy of Management Review, 28, 447-465

Arora, A., \& Gambardella, A. (1997). Domestic markets and international competitiveness: Generic and product-specific competencies in the engineering sector. Strategic Management Journal, 18, 53-74.

Aulakh, P., Masaaki, K., \& Teegen, H. (2000). Export strategies and performance of firms from emerging economies: Evidence from Brazil, Chile and Mexico, Academy of Management Journal, 43, 342-361.

.Baum, C.F., Schaffer, M.E. \& Stillman, S. (2003). Instrumental variables and GMM: Estimation and testing. The Stata Journal, 3, 1-31.

Bhaumik, S. K., Driffield, N., \& Pal, S. (2010). Does ownership structure of emerging-market firms affect their OFDI?, The case of the Indian automotive and pharmaceutical sectors. Journal of International Business Studies, 41, 437-450.

Blundell, R., \& Bond, S. (1998). Initial Conditions and Moment Restrictions in Dynamic Panel Data Models. Journal of Econometrics, 87, 115-143.

Brandt, L., \& Zhu, X.D. (2000). Redistribution in a decentralized economy: growth and inflation in China under reform. Journal of Political Economy, 108, 422-439.

Brush, T., Bromiley, P. \& Hendrickx, M. (2000). The cash flow hypothesis for sales growth and firm performance, Strategic Management Journal, 21, 455-472.

Buck, T., Liu, X., \& Skovoroda, R. (2008). Top executive pay in China: a new laboratory for research?, Journal of International Business Studies, 39, 833-850. 
Carroll, R., \& Hannan, M.T. (1995). Resource partitioning. In Carroll, G.R \& Hannan, M.T (Eds.), Organizations in Industry, Oxford University Press, New York.

Chan, C., Markino, S., \& Isobe, T. (2010). Does subnational region matter? Foreign affiliate performance in the United States and China, Strategic Management Journal, 31, 1226-1243.

Child, J., \& Tse, D. (2001). Chinas transition and its implications for international business. Journal of International Business Studies, 32, 5-21.

Chizema, A. (2008). Institutions and voluntary compliance: The disclosure of executive pay in Germany, Corporate Governance: An International Review, 16, 359-374.

Cui, L., \& Jiang, F. (2012). State ownership effect on firms' FDI ownership decisions under institutional pressure: a study of Chinese outward-investing firms, Journal of International Business Studies, 43, 264-284.

Datta, D., Musteen, M., \& Herrmann, P. (2009). Board characteristics, managerial incentives and the choice between foreign acquisitions and international joint ventures, Journal of Management, 35, 928-953.

DeFusco, R., Zorn, T., \& Johnson, R. (1991). The association between executive stock option plan changes and managerial decision making, Financial Management, 20, 36-43.

Delios, A., Wu, Z., \& Zhou, N. (2006). A new perspective on ownership identities in Chinas listed companies, Management and Organization Review, 2, 319-343.

Deng, P. (2009). Why Do Chinese firms tend to acquire strategic assets in international expansion? Journal of World Business, 44, 74-84.

Du, J., Lu, Y., \& Tao, Z. (2008). Economic institutions and FDI location choice: Evidence from US manufacturing firms in China. Journal of Comparative Economics, 36, 412-429. 
Economists (2011). Comparing Chinese provinces with countries: All the parties in China.

http://www.economist.com.hk/content/chinese_equivalents (accessed on 16 February 2013).

Fama, E., \& Jensen, M. (1983). Separation of ownership and control, Journal of Law and Economics, 26, 301-325.

Fan, G., Wang, X., Zhang, L. W. \& Zhu, H. P. (2003). Marketization for China's provinces, Economic Research Journal, 3, 9-18.

Fan, G., Wang, X., \& Zhu, H. (2010). NERI Index of Marketization for China's Provinces: 2009 Report (in Chinese), Economic Science Press, Beijing.

Filatotchev, I., Strange, R., Piesse, J., \& Lien, Y. C. (2007). FDI by firms from newly industrialised economies in emerging markets: corporate governance, entry mode and location. Journal of International Business Studies, 38, 556-572.

Filatotchev, I., \& Wright, M. (2011). Agency perspectives on corporate governance of multinational enterprises, Journal of Management Studies, 48, 471-486.

Firth, M., Fung, P., \& Rui, O. (2007). How ownership and corporate governance influence chief executive pay in Chinas listed firms, Journal of Business Research, 60, 776-785.

Gao, G., Murray, J., Kotabe, M., \& Lu, J. (2010). A strategy tripod perspective on export behaviors: Evidence from domestic and foreign firms based in an emerging economy, Journal of International Business Studies, 41, 377-396.

Globerman, S., \& Shapiro, D. (2003). Governance infrastructure and U.S. foreign direct investment, Journal of International Business Studies, 34, 19-39.

Golden, B. \& Zajac, E. (2001). When will boards influence strategy? Inclination x power = strategic change, Strategic Management Journal, 22, 1087-1111. 
Gomez-Mejia, L., \& Wiseman, R. (1997). Reframing executive compensation: An assessment and outlook, Journal of Management, 23, 291-374.

Goranova, M., Alessandri, T., Brandes, P., \& Dharwadkar, R. (2007). Managerial ownership and corporate diversification: a longitudinal view, Strategic Management Journal, 28, 211225.

Granger, C., Huangb, B., \& Yang, C. (2000). A bivariate causality between stock prices and exchange rates: evidence from recent Asian flu, Quarterly Review of Economics and Finance, 40, 337-354.

Granville, B., \& Leonard, C. (2010). Do informal institutions matter for technological change in Russia? The impact of communist norms and conventions, 1998-2004, World Development, $38,155-169$.

Hart, O. (1983). The market mechanism as an incentive scheme, Bell Journal of Economics, 14, 366-382.

Himmelberg, C. P., Hubbard, R. G. \& Palia, D. (1999). Understanding the determinants of managerial ownership and the link between ownership and performance. Journal of Financial Economics, 53, 353-384.

Hitt, M., Hoskission, R., \& Kim, H. (1997). International diversification: Effects on innovation and firm performance in product-diversified firms, Academy of Management Journal, 40, 767-798.

Hoskisson, R., Wright, M., Filatotchev, I., \& Peng, M. (2013). Emerging multinationals from mid-range economies: The influence of institutions and factor markets. Journal of Management Studies, forthcoming. 
Hoskisson, R. E., Eden, L., Lau, C. M. \& Wright, M. (2000). Strategy in emerging economies. Academy of Management Journal, 43, 249-267.

Jensen, M., \& Murphy, K. (1990). Performance pay and top management incentives, Journal of Political Economy, 98, 225-264.

La Porta, R., Lopez-De-Silanes, F., \& Shleifer, A. (1998). Law and finance, Journal of Political Economy, 106, 1113-1155.

Lien, Y.-C., Piesse, J., Strange, R., \& Filatotchev, I. (2005). The role of corporate governance in FDI decisions: Evidence from Taiwan. International Business Review, 14, 739-763.

Liu, X., Lu, J., Filatotchev, I., Buck, T., \& Wright, M. (2010). Returnee entrepreneurs, knowledge spillovers and innovation in high-tech firms in emerging economies, Journal of International Business Studies, 41, 1183-1197

Liu, Y., Li, Y., \& Xue, J. ( 2011). Ownership, strategic orientation and internationalization in emerging markets, Journal of World Business, 46, 381-393.

Lu, J., Liu, X., \& Wang, H. (2011). Motives for outward FDI of Chinese private firms: Firm resources, industry dynamics, and government policies. Management and Organization Review, 7, 223-248.

Luo, Y., Xue, Q., \& Han, B. (2010). How emerging market governments promote OFDI: Experience from China, Journal of World Business, 45, 68-79.

Mani, S., Anita, K. D. \& Rindfleisch, A. (2007). Entry mode and equity level: A multilevel examination of foreign direct investment ownership structure. Strategic Management Journal, 28, 857-66.

Mathews, J. (2006). Dragon multinationals: New players in 21st century globalization, Asia Pacific Journal of Management, 23, 5-27. 
McEvily, B., \& Zaheer, A. (1999). Bridging ties: a source of firm heterogeneity in competitive capabilities, Strategic Management Journal, 20, 1133-1156.

Meyer, K., \& Nguyen, H. (2005). Foreign investment strategies and sub-national institutions in emerging markets: Evidence from Vietnam, Journal of Management Studies, 42, 63-91.

Meyer, M. (2008). Chinas second economic transition: Building national markets, Management and Organization Review, 4, 3-15.

Mitchell, W., Shaver, M., \& Yeung, B. (1992). Getting there in a global industry: Impacts on performance of changing international presence, Strategic Management Journal, 13, 419432.

MOFCOM. (2013). Brief Statistical Bulletin of China's Outward Foreign Direct Investment in 2012, Beijing, China: Ministry of Commerce.

MOFCOM. (2004). Guidance Catalogue of Countries and Industries for Overseas Investment. Beijing, China: Ministry of Commerce.

Murphy, K. (1999). Executive compensation. In Ashenfelter O, Card D (Eds.), Handbook of Labour Economics, Vol 3. (pp. 1-89). North-Holland: Amsterdam.

Musteen, M., Datta, D., \& Herrmann, P. (2008). Ownership structure and CEO compensation: Implications for the choice of foreign market entry modes, Journal of International Business Studies, 39, 1-18.

Nair-Reichert, U. \& Weinhold, D. (2001). Causality tests for cross-country panels: a new look at FDI and economic growth in developing countries, Oxford Bulletin of Economics and Statistics, 63, 153-171.

Naughton, B. (1995). Growing out of the plan: Chinese economic reform, 1979-1993. Cambridge: Cambridge University Press. 
North, D. C. (1990). Institutions, Institutional Change, and Economic Performance, Harvard University Press: Cambridge, MA.

Oxelheim, L., \& Randøy, T. (2005). The Anglo-American financial influence on CEO compensation in non-Anglo-American firms, Journal of International Business Studies, 36, $470-483$.

Palmer, T., \& Wiseman, R. (1999). Decoupling risk taking from income stream uncertainty: A holistic approach, Strategic Management Journal, 20, 1037-1062.

Peng, M., Wang, D. \& Jiang, Y. (2008). An Institutional-based view of international business strategy: A focus on emerging economies, Journal of International Business Studies, 39, 920-936.

Rajgopal, S. \& Shevlin, T. (2002). Empirical evidence on the relation between stock option compensation and risk taking, Journal of Accounting and Economics, 33, 145-171.

Rost, K., \& Osterloh, M. (2009). Management fashion pay-for-performance for CEOs. Schmalenbach Business Review, 61, 119-149.

Roth, K., \& O'Donnell, S. (1996). Foreign subsidiary compensation strategy: An agency theory perspective, Academy of Management Journal, 39, 678-703.

Rui, H. \& Yip, G. (2008). Foreign acquisitions by Chinese firms: A strategic intent perspective, Journal of World Business, 43, 213-226.

Sanders, W. \& Carpenter, M. (1998). Internationalization and firm governance: The roles of CEO compensation, top team composition, and board structure, Academy of Management Journal, 41, 158-178.

Sanders, W., \& Hambrick, D. (2007). Swing for the fences: the effects of CEO stock options on company risk taking and performance, Academy of Management Journal, 50, 1055-1078. 
Schlevogt, K. (2001). Institutional and organisational factors affecting effectiveness: Geoeconomic comparison between Shanghai and Beijing, Asia Pacific Journal of Management, 18, 519-551.

Shinkle, G. \& Kriauciunas, A. (2010). Institutions, size and age in transition economies: Implications for export growth, Journal of International Business Studies, 41, 267-286.

Strange, R., Filatotchev, I., Buck, T. \& Wright, M. (2009). Corporate governance and international business, Management International Review, 49, 395-407.

Tihanyi, L., Hoskisson, R., Johnson, R. \& Wan, W. (2009). Technological competence and international diversification: the role of managerial incentives, Management International Review, 49, 409-431.

Van den Berghe, L. \& Levrau, A. (2004). Evaluating Boards of Directors: What constitutes a good corporate board? Corporate Governance: An International Review, 12, 461-478.

Wang, Q., Wong, T. \& Xia, L. (2008). State ownership, the institutional environment, and auditor choice: Evidence from China, Journal of Accounting and Economics, 46, 112-134.

Wang, Q., Zhang, Y., Chen, Z. \& Lu, M. (2007). On China's development model: The cost and benefits of China's decentralization approach to transition, Economic Research Journal, 1, 5-16.

Wong, S. (2011). Uses and limits of conventional corporate governance instruments: Analysis and guidance for reform. The Global Corporate Governance Forum of the World Bank Group at http://ssrn.com/abstract=1455166 (accessed on 30 May 2012).

The World Bank Group, (2008). Doing Business in China in 2008 at http://www.doingbusiness.org/reports/subnational-reports/china (accessed on 17 February 2013). 
Yamakawa. Y., Peng, M. \& Deeds, D. (2008). What drives new ventures to internationalize from emerging to developed economies?, Entrepreneurship: Theory and Practice, 32, 5982.

Young, M., Peng, M., Ahlstrom, D., Bruton, G. \& Jiang, Y. (2008). Corporate governance in EEs: A review of the principal-principal perspective, Journal of Management Studies, 45, 196-220.

Zahra, S. A., Neubaum, D. O. \& Huse, M. (2000). Entrepreneurship in medium-size companies: Exploring the effects of ownership and governance systems. Journal of Management, 26, 947-976.

\section{Acknowledgements:}

The authors would like to thank Senor Editor, Professor Wayne Cascio and three anonymous reviewers for their constructive comments on an earlier version of the paper. Financial support from the Leverhulme Trust (RPG-160) is gratefully acknowledged. 
Table 1: Correlation matrix

\begin{tabular}{|c|c|c|c|c|c|c|c|c|c|c|c|c|c|c|c|c|c|c|}
\hline & Mean & Std. Dev. & 1 & 2 & 3 & 4 & 5 & 6 & 7 & 8 & 9 & 10 & 11 & 12 & 13 & 14 & 15 & 16 \\
\hline 1 Share of OFDI & 0.106 & 0.235 & 1.000 & & & & & & & & & & & & & & & \\
\hline 2 Extent of OFDI & 0.016 & 0.078 & 0.445 & 1.000 & & & & & & & & & & & & & & \\
\hline $\begin{array}{l}3 \text { TE pay } \\
4 \text { TE equity }\end{array}$ & 11.59 & 1.237 & 0.093 & 0.106 & 1.000 & & & & & & & & & & & & & \\
\hline & 0.003 & 0.031 & 0.053 & 0.016 & 0.031 & 1.000 & & & & & & & & & & & & \\
\hline $\begin{array}{l}\text { product markets } \\
6 \text { Index of factor }\end{array}$ & 8.677 & 1.355 & 0.166 & 0.106 & 0.182 & 0.057 & 1.000 & & & & & & & & & & & \\
\hline $\begin{array}{l}\text { Markets } \\
7 \text { Index of market } \\
\text { institutions and }\end{array}$ & 5.978 & 2.755 & 0.160 & 0.110 & 0.215 & 0.038 & 0.467 & 1.000 & & & & & & & & & & \\
\hline $\begin{array}{l}\text { legal systems } \\
8 \text { State }\end{array}$ & 7.024 & 3.410 & 0.151 & 0.092 & 0.185 & 0.036 & 0.446 & 0.890 & 1.000 & & & & & & & & & \\
\hline $\begin{array}{l}\text { shareholdings } \\
9 \text { TEs' }\end{array}$ & 0.438 & 0.183 & -0.019 & -0.029 & 0.003 & -0.037 & -0.047 & -0.008 & -0.033 & 1.000 & & & & & & & & \\
\hline $\begin{array}{l}\text { international } \\
\text { experience } \\
10 \text { Policy }\end{array}$ & 0.037 & 0.189 & 0.106 & 0.054 & 0.042 & -0.018 & 0.112 & 0.104 & 0.102 & -0.019 & 1.000 & & & & & & & \\
\hline $\begin{array}{l}\text { orlentated } \\
\text { industry } \\
11 \text { Foreign }\end{array}$ & 0.554 & 0.497 & 0.104 & -0.023 & -0.100 & 0.036 & -0.172 & 0.105 & 0.089 & -0.052 & -0.001 & 1.000 & & & & & & \\
\hline shareholdings & 0.047 & 7.193 & 0.150 & 0.158 & 0.115 & -0.011 & 0.096 & 0.090 & 0.091 & -0.086 & 0.132 & 0.092 & 1.000 & & & & & \\
\hline $\begin{array}{l}12 \text { Board size } \\
13 \text { Independent }\end{array}$ & 9.698 & 2.212 & -0.016 & 0.007 & 0.099 & -0.012 & -0.050 & -0.043 & -0.038 & 0.030 & 0.040 & -0.045 & 0.073 & 1.000 & & & & \\
\hline $\begin{array}{l}\text { directors } \\
14 \text { Intangible }\end{array}$ & 0.327 & 0.073 & 0.003 & -0.005 & -0.011 & 0.017 & 0.095 & 0.126 & 0.086 & -0.013 & 0.016 & 0.002 & -0.143 & -0.230 & 1.000 & & & \\
\hline assets & 0.041 & 0.059 & -0.083 & -0.057 & -0.089 & 0.026 & -0.070 & -0.059 & -0.081 & -0.029 & 0.001 & 0.014 & -0.033 & -0.066 & 0.034 & 1.000 & & \\
\hline 15 Firm size & 11.393 & 1.555 & 0.172 & 0.129 & 0.276 & -0.029 & 0.162 & 0.163 & 0.147 & -0.018 & 0.085 & 0.065 & 0.177 & 0.211 & -0.078 & -0.178 & 1.000 & \\
\hline $\begin{array}{l}16 \text { Firm age } \\
17 \text { Return on }\end{array}$ & 12.845 & 3.943 & 0.037 & 0.057 & 0.020 & -0.073 & 0.167 & 0.118 & 0.146 & 0.010 & 0.014 & -0.133 & 0.020 & -0.053 & 0.029 & 0.063 & -0.122 & 1.000 \\
\hline $\operatorname{assets}_{(t-1)}$ & 0.015 & 0.082 & 0.066 & 0.051 & 0.180 & 0.041 & 0.061 & 0.083 & 0.082 & -0.013 & 0.017 & -0.018 & 0.073 & 0.085 & -0.030 & -0.097 & 0.391 & -0.108 \\
\hline
\end{tabular}

Note: 1 . All correlation coefficients more than 0.031 or less than -0.031 are significant at the $5 \%$ level or higher.

2. TE denotes top executive, and TE pay was measured in the log value. 
Table 2: The destinations of OFDI by the sample firms in the period of 2002-2007

\begin{tabular}{lll}
\hline Destination & Destination & Destination \\
\hline Afghanistan & Hungary & Romania \\
Antigua \& & & \\
Barbuda & India & Russia \\
Argentina & Indonesia & South Africa \\
Australia & Italy & Samoa \\
Bangladesh & Japan & Saudi Arabia \\
Belgium & Kazakhstan & Singapore \\
Bermuda & Korea Rep. & Spain \\
Br. Virgin Is & Laos, PDR & Suriname \\
Brazil & Liberia & Sweden \\
Bulgaria & Luxembourg & Switzerland \\
Canada & Macau & Tadzhikistan \\
Cayman Is & Malaysia & Tanzania \\
Congo & Malta & Thailand \\
Croatia Rep & Mexico & Turkey \\
& & United Arab \\
Czech Rep & Mongolia & Emirates \\
Denmark & Netherlands & United Kingdom \\
Ecuador & Nigeria & United States \\
Finland & Pakistan & Venezuela \\
France & Panama & Vietnam \\
Germany & Philippines & \\
Ghana & Poland & \\
Honduras & Portugal & \\
\hline
\end{tabular}

Table 3: Results from the Panel Causality Test

\begin{tabular}{lcc}
\hline Causality & F test & Inferences \\
\hline Extent of OFDI $\Rightarrow$ TE pay & $8.120^{* * *}$ & Yes \\
Share of OFDI $\Rightarrow$ TE pay & $5.801^{* * *}$ & Yes \\
Extent of OFDI $\Rightarrow$ TE equity ownership & $4.078^{* * *}$ & Yes \\
Share of OFDI $\Rightarrow$ TE equity ownership & $11.787^{* * *}$ & Yes \\
\hline
\end{tabular}

Note: $1 . * * *$ and $* * *$ represent significance at the $0.05,0.01$ and 0.001 levels, respectively.

2. TE denotes top executive, and TE pay was measured in the log value. 
Table 4: The impact of top executive compensation and subnational institutions on extent of OFDI

\begin{tabular}{|c|c|c|c|c|c|c|c|}
\hline \multirow[t]{2}{*}{ Variables } & \multicolumn{7}{|c|}{ Dependent variable: Extent of OFDI } \\
\hline & Model 1 & Model 2 & Model 3 & Model 4 & Model 5 & Model 6 & Model 7 \\
\hline TE pay & & $\begin{array}{c}0.002 * * * \\
(0.001)\end{array}$ & $\begin{array}{c}0.007 * * * \\
(0.001)\end{array}$ & $\begin{array}{c}0.002 * * * \\
(0.001)\end{array}$ & $\begin{array}{c}0.002 * * * \\
(0.002)\end{array}$ & $\begin{array}{c}0.002 * * * \\
(0.002)\end{array}$ & $\begin{array}{c}0.001 * * * \\
(0.002)\end{array}$ \\
\hline TE equity ownership & & $\begin{array}{c}0.025 * * * \\
(0.002)\end{array}$ & $\begin{array}{l}0.084 * * * \\
(0.006)\end{array}$ & $\begin{array}{c}0.025 * * * \\
(0.002)\end{array}$ & $\begin{array}{c}0.031 * * * \\
(0.003)\end{array}$ & $\begin{array}{c}0.032 * * * \\
(0.001)\end{array}$ & $\begin{array}{c}0.023 * * * \\
(0.003)\end{array}$ \\
\hline $\begin{array}{l}\text { Index of product markets } \\
\text { (IE1) }\end{array}$ & & $\begin{array}{c}0.005 * * * \\
(0.004)\end{array}$ & & & $\begin{array}{c}0.001 \\
(0.004)\end{array}$ & & \\
\hline $\begin{array}{l}\text { Index of factor markets } \\
\text { (IE2) }\end{array}$ & & & $\begin{array}{c}0.011 * * * \\
(0.002)\end{array}$ & & & $\begin{array}{c}0.009 \\
(0.002)\end{array}$ & \\
\hline $\begin{array}{l}\text { Index of market } \\
\text { intermediate institutions } \\
\text { and legal systems (IE3) }\end{array}$ & & & & $\begin{array}{l}0.003 * * * \\
(0.001)\end{array}$ & & & $\begin{array}{c}0.001 \\
(0.001)\end{array}$ \\
\hline $\begin{array}{l}\text { TE pay X IE1 } \\
\text { TE equity ownership X IE1 }\end{array}$ & & & & & $\begin{array}{c}0.002 \\
(0.000) \\
0.008 * * \\
(0.003)\end{array}$ & & \\
\hline TE pay X IE2 & & & & & & $\begin{array}{c}0.000 \\
(0.002)\end{array}$ & \\
\hline TE equity ownership X IE2 & & & & & & $\begin{array}{c}0.010 * * * \\
(0.004)\end{array}$ & \\
\hline TE pay X IE3 & & & & & & & $\begin{array}{c}0.001 \\
(0.000)\end{array}$ \\
\hline TE equity ownership X IE3 & & & & & & & $\begin{array}{c}0.006 * * * \\
(0.002)\end{array}$ \\
\hline Control variables & & & & & & & \\
\hline Policy orientated industry & $\begin{array}{c}0.042 * * * \\
(0.005)\end{array}$ & $\begin{array}{c}0.040 * * * \\
(0.003)\end{array}$ & $\begin{array}{l}0.037 * * * \\
(0.006)\end{array}$ & $\begin{array}{c}0.040 * * * \\
(0.003)\end{array}$ & $\begin{array}{c}0.021 * * * \\
(0.006)\end{array}$ & $\begin{array}{c}0.020 * * * \\
(0.006)\end{array}$ & $\begin{array}{c}0.011 * * * \\
(0.005)\end{array}$ \\
\hline State shareholdings & $\begin{array}{l}0.001 \\
(0.000)\end{array}$ & $\begin{array}{l}0.000 \\
(0.000)\end{array}$ & $\begin{array}{l}0.001 \\
(0.002)\end{array}$ & $\begin{array}{l}0.001 \\
(0.001)\end{array}$ & $\begin{array}{l}0.000 \\
(0.000)\end{array}$ & $\begin{array}{l}0.001 \\
(0.001)\end{array}$ & $\begin{array}{l}0.001 \\
(0.000)\end{array}$ \\
\hline Foreign shareholdings & $\begin{array}{l}0.001 * * * \\
(0.002)\end{array}$ & $\begin{array}{l}0.001 * * * \\
(0.001)\end{array}$ & $\begin{array}{l}0.002 * * * \\
(0.002)\end{array}$ & $\begin{array}{l}0.002 * * \\
(0.002)\end{array}$ & $\begin{array}{l}0.001 \\
0.001\end{array}$ & $\begin{array}{c}0.001 \dagger \\
0.002\end{array}$ & $\begin{array}{l}0.001 \\
0.002\end{array}$ \\
\hline Board size & $\begin{array}{l}-0.008 \\
(0.001)\end{array}$ & $\begin{array}{l}-0.001 \\
(0.000)\end{array}$ & $\begin{array}{l}-0.001 \\
(0.001)\end{array}$ & $\begin{array}{l}-0.001 \\
(0.000)\end{array}$ & $\begin{array}{l}-0.001 \\
(0.000)\end{array}$ & $\begin{array}{l}-0.001 \\
(0.000)\end{array}$ & $\begin{array}{l}-0.001 \\
(0.000)\end{array}$ \\
\hline Independent directors & $\begin{array}{c}0.025 \\
(0.004)\end{array}$ & $\begin{array}{c}0.001 \\
(0.002)\end{array}$ & $\begin{array}{c}0.001 \\
(0.003)\end{array}$ & $\begin{array}{c}0.001 \\
(0.003)\end{array}$ & $\begin{array}{c}0.001 \\
(0.003)\end{array}$ & $\begin{array}{c}0.003 \\
(0.002)\end{array}$ & $\begin{array}{c}0.002 \\
(0.001)\end{array}$ \\
\hline $\begin{array}{l}\text { TEs' international } \\
\text { experience }\end{array}$ & $\begin{array}{c}0.076 * * \\
(0.005)\end{array}$ & $\begin{array}{l}0.006^{*} \\
(0.001)\end{array}$ & $\begin{array}{l}0.010^{*} \\
(0.008)\end{array}$ & $\begin{array}{l}0.006^{*} \\
(0.002)\end{array}$ & $\begin{array}{l}0.004 * \\
(0.003)\end{array}$ & $\begin{array}{c}0.005 \\
(0.003)\end{array}$ & $\begin{array}{c}0.007 \\
(0.004)\end{array}$ \\
\hline Intangible assets & $\begin{array}{c}-0.040 * \\
(0.009) \\
0.007 * * *\end{array}$ & $\begin{array}{l}-0.024 * * \\
(0.001) \\
0.004 * * *\end{array}$ & $\begin{array}{l}-0.036 * * \\
(0.004) \\
0.004 * * *\end{array}$ & $\begin{array}{c}-0.025 * * \\
(0.006) \\
0.004 * * *\end{array}$ & $\begin{array}{c}-0.023 * * \\
(0.004) \\
0.004 * *\end{array}$ & $\begin{array}{c}-0.020 * * \\
(0.004) \\
0.004 * *\end{array}$ & $\begin{array}{l}-0.005 \\
(0.004) \\
0.003 * *\end{array}$ \\
\hline Firm size & $\begin{array}{l}0.007 * * * \\
(0.001)\end{array}$ & $\begin{array}{l}0.004^{2} \\
(0.001)\end{array}$ & $\begin{array}{c}0.004 * * * \\
(0.002)\end{array}$ & $\begin{array}{c}0.004 \\
(0.002)\end{array}$ & $(0.001)$ & $\begin{array}{l}0.004 * * \\
(0.002)\end{array}$ & $\begin{array}{l}0.003 * * \\
(0.002)\end{array}$ \\
\hline Firm age & $\begin{array}{c}0.001 * * * \\
(0.003)\end{array}$ & $\begin{array}{c}0.001 * * * \\
(0.004)\end{array}$ & $\begin{array}{c}0.001 * * * \\
(0.004)\end{array}$ & $\begin{array}{c}0.001 * * * \\
(0.004)\end{array}$ & $\begin{array}{c}0.001 * * \\
(0.003)\end{array}$ & $\begin{array}{c}0.001 * * \\
(0.003)\end{array}$ & $\begin{array}{c}0.003 * * \\
(0.003)\end{array}$ \\
\hline${\text { Return on } \operatorname{assets}_{(\mathrm{t}-1)}}$ & $\begin{array}{c}0.012 \\
(0.014) \\
\end{array}$ & $\begin{array}{c}0.001 \\
(0.002)\end{array}$ & $\begin{array}{c}0.004 \\
(0.018) \\
\end{array}$ & $\begin{array}{c}0.001 \\
(0.002)\end{array}$ & $\begin{array}{c}0.003 \\
(0.002)\end{array}$ & $\begin{array}{c}0.003 \\
(0.002)\end{array}$ & $\begin{array}{c}0.003 \\
(0.002)\end{array}$ \\
\hline Adjusted R-squared & 0.062 & 0.115 & 0.127 & 0.153 & 0.118 & 0.134 & 0.158 \\
\hline Sargan test & 0.109 & 0.157 & 0.273 & 0.148 & 0.170 & 0.231 & 0.119 \\
\hline Observations & 5355 & 5355 & 5355 & 5355 & 5355 & 5355 & 5355 \\
\hline
\end{tabular}

Note: $1 . *, * *$ and $* * *$ represent significance at the $0.05,0.01$ and 0.001 levels, respectively.

2. IE represents institutional environment factors, TE denotes top executive, and TE pay was measured in the log value. 
Table 5: The impact of top executive compensation and subnational institutions on share of OFDI in total investment

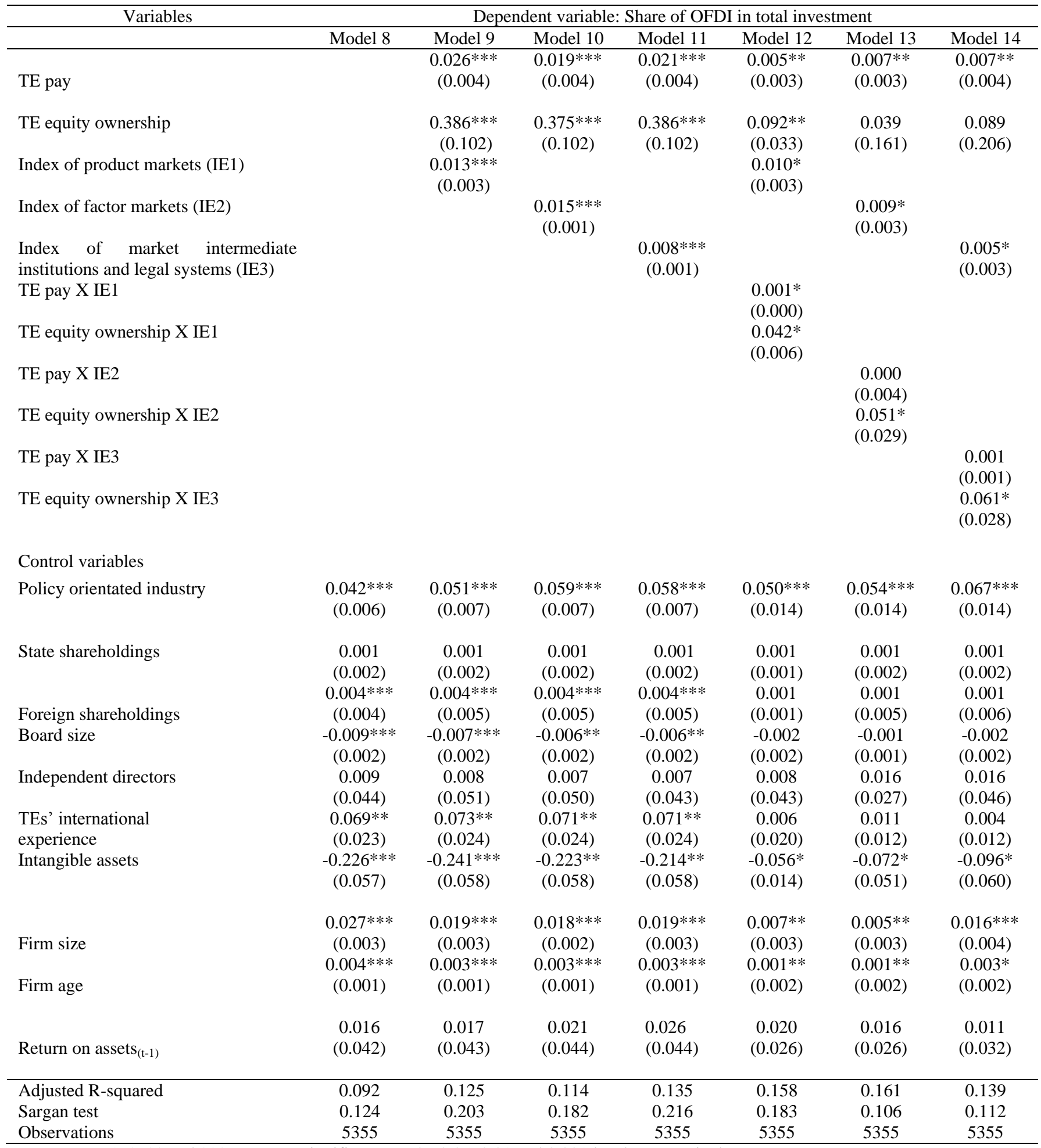

Note: $1 . *, * *$ and $* * *$ represent significance at the $0.05,0.01$ and 0.001 levels, respectively.

2. IE represents institutional environment factors, TE denotes top executive, and TE pay was measured in the $\log$ value. 


\section{Appendix Table 1: Description of the NERI Indices}

1 The relationship between government and markets

1a Government allocation of resources in GDP

$1 \mathrm{~b}$ Tax and non-tax burden of farmers

1c Government intervention in enterprises

1d Non-tax burden on enterprises

1e Size of government

2 Development of non-state enterprise sector

2a Share of the non-state sector in gross industrial output

$2 b$ Share of the non-state sector in total investment in fixed assets

2c Share of the non-state sector in total urban employment

3 Development of product markets

3a Percentage of products with market-determined prices

$3 \mathrm{~b}$ Degree of local protectionism or trade barriers

4 Development of factor markets

4a Development of the financial sector

$4 \mathrm{~b}$ Degree of absorption of foreign capital

4c Labor mobility

$4 \mathrm{~d}$ Development of the technology market

5 Market-intermediate institutions and legal framework

5a Development of market intermediaries (share of lawyers in local population and share of independent accountants in local population)

5 b Protection of intellectual property rights

5 c Protection of consumers' rights

Source: Fan, Wang, \& Zhu, (2010). NERI Index of Marketization for China's Provinces: 2009 Report (in Chinese),

Economic Science Press, Beijing. 
Appendix 2: NERI indices for year 2007

\begin{tabular}{lrrr}
\hline Province & $\begin{array}{c}\text { Product } \\
\text { market } \\
\text { index }\end{array}$ & $\begin{array}{c}\text { Factor } \\
\text { market } \\
\text { index }\end{array}$ & $\begin{array}{c}\text { Market-Intermediate } \\
\text { institution and legal } \\
\text { systems }\end{array}$ \\
\hline Qindex
\end{tabular}

Note: Provinces in the table are sorted in ascending order of the index of product markets; Shanxi (1) represents the province with Taiyuan as its capital,

while Shanxi (3) represents the province with Xian as its capital. These are different names in Chinese. The number in brackets represents the tone in Chinese pronunciation. 